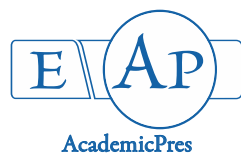

\title{
Curcumin Alleviates Potassium Bromate-Induced Hepatic Damage by Repressing CRP Induction through TNF- $\alpha$ and IL-1 $\beta$ and by Suppressing Oxidative Stress
}

\author{
Omowumi O. ADEWALE ${ }^{1 *}$, Seun F. AKOMOLAFE ${ }^{2}$, \\ Nnaemeka T. ASOGWA ${ }^{3}$ \\ ${ }^{1}$ Osun State University, Faculty of Basic and Applied Sciences, Department of Biochemistry, Cancer Research and Molecular Toxicology \\ Laboratories, Osogbo, Nigeria; adewaleomowumi13@gmail.com (*orresponding author) \\ ${ }^{2}$ Ekiti State University, Faculty of Science, Department of Biochemistry, Ado Ekiti, Nigeria; purposefulseun@yahoo.co.uk \\ ${ }^{3}$ Central Research Laboratories, Ilorin, Kwara State, Nigeria; emekaasogwanigltd@gmail.com
}

\begin{abstract}
This study evaluated the prospective molecular and biochemical mechanisms behind the hepatoprotective effects of curcumin in Wistar rats exposed to $\mathrm{KBrO}_{3}$. Techniques for assessment of hepatic oxidative injury and histological biomarkers were used. The concentrations of proteins connected with inflammation (e.g. tumor necrosis factor-alpha (TNF- $\alpha$ ), interleukins $1 \beta$ (IL-1 $\beta$ ) and C-reactive protein (CRP)) were estimated by enzyme-linked immunosorbent assay (ELISA) techniques. Results showed that, curcumin administered orally at a dose of $20 \mathrm{mg} / \mathrm{kg}$ for 28 days significantly suppressed the activities of serum transaminases and alkaline induced by $\mathrm{KBrO}_{3}$ administration $(20 \mathrm{mg} / \mathrm{kg}$, twice weekly) and protected the integrity of the liver tissue. Also, curcumin at the tested dose abridged the $\mathrm{KBrO}_{3}$-induced increase in hepatic malondialdehyde (MDA) levels and reversed $\mathrm{KBrO}_{3}$ mediated reduction in activities of hepatic antioxidant molecules including reduced glutathione (GSH), total thiol (TSH), glutathione peroxidase (GPx), catalase and superoxide dismutase (SOD). In addition, curcumin significantly assuaged inflammatory response in $\mathrm{KBrO}_{3}$-lesioned liver as revealed by the decrease in inflammatory biomarkers. This study suggests that curcumin exhibits a protective effect via induction of hepatic detoxification proteins and inhibition of inflammatory proteins in addition to its antioxidative ability in $\mathrm{KBrO}_{3}$-induced hepatic injury in rats.
\end{abstract}

Keywords: C-reactive protein; curcumin; cytokines; hepatoprotective; potassium bromate

\section{Introduction}

Potassium bromate $\left(\mathrm{KBrO}_{3}\right)$ is required for a wide range of activities in many industries such as food and cosmetics industries (IARC,1986). However, exposure to unwarranted level of potassium bromate via, for instance, food can induce hepatic damage among other organ damage including neurotoxicity, and tumor induction in experimental animals or renal carcinomas induction in animals and humans (De Angelo et al., 1998; Zhang et al., 2010). The mechanisms of $\mathrm{KBrO}_{3}$-induced hepatotoxicity have been identified to involve oxidative stress among others (Chipman et al., 1998; Umemura et al., 1998; Murata et al., 2001; Li et al., 2015; Tsuchiyah et al., 2018). $\mathrm{KBrO}_{3}$ results in significant reduction in the levels and activities of non-enzymatic and enzymatic antioxidant molecules including reduced glutathione (GSH), superoxide dismutase (SOD), glutathione peroxidase (GPx) and catalase in the liver and many other organs (Khan et al., 2012; Sahreen et al., 2013; Tsuchiya et al., 2018). The involvement of reactive oxygen species (ROS) such as $\mathrm{H}_{2} \mathrm{O}_{2}$, hydroxyl radicals (OH.) and superoxide anion $\left(\mathrm{O}_{2}^{-}\right)$in $\mathrm{KBrO}_{3}$-induced hepatotoxicity has been reported thereby culminating in oxidative stress, which is one of the important mechanisms for several pathological conditions including hepatic injury, tissue wasting, neoplastic transformation, and tumor generation (Nakae et al., 1997; Wills et al., 2006; Pradeep et al., 2007; Uchida et al., 2018).

Hepatocytes are known to constantly secrete vast array of proteins which serve crucial functions in the activation of innate immunity (Zhou et al., 2016), and these proteins are categorized as acute-phase proteins (APPs). The production of these APPs are enhanced by many inflammatory cytokines, including Interleukin 1 beta (IL-1 $\beta$ ), and tumor 
338

necrosis factor- alpha (TNF- $\alpha$ ) (Zhou et al., 2016). These Inflammatory cytokines have been reported to be early mediators connected to tissue damage and repair, and that high level of IL- $1 \beta$ is connected to liver damage while TNF$\alpha$ may also be induced in hepatic damage (DeCicco et al., 1998). C-reactive protein (CRP) is one of the acuteproteins that is critically involved in inflammatory responses, it is generally employed as a biomarker to identify acute and chronic inflammation (Wang and Sun, 2009). Improper elevation of CRP has been frequently observed in some malignancies including hepatocellular (Wang and Sun, 2009). Like some other gene products, the secretion of CRP in hepatocytes is predominantly induced at the transcriptional level and the level can be enhanced by proinflammatory mediators including IL- $1 \beta$ and TNF- $\alpha$ (Castell et al., 1990; Wang and Sun, 2009). Elevated CRP has been observed in patients with different cancer types and has been suggested to be a secondary response to tumor necrosis, local tissue damage, and associated inflammation in cancer patients (De Mello et al., 1983; Falconer et al., 1995; Gockel et al., 2006; Crumley et al., 2006). Since various studies have demonstrated the correlation of elevated CRP levels with incidence of malignancies, agents with CRP-lowering capacity are being considered to be potentially effective in cancer prevention and therapy (Wang and Sun, 2009). Other attempts have targeted the inducers of CRP i.e. the cytokines (e.g. IL-1 $\beta$, and TNF alpha) to indirectly suppress CRP in cancers and diseases associated with Inflammation (Wang and Sun, 2009). A number of agents (COX inhibitors and lipid-lowering agents) have provided promising results in lowering serum levels of CRP in cancer therapy (Kennon et al., 2001; Zimmerman et al., 2003; Nissen et al., 2005; Prasad, 2006). Vast array of dietary active compounds have also been demonstrated for their anti-inflammatory and anticarcinogenic activities (Fürst and Zündorf, 2014; Griffiths et al., 2016). However, assessment of their capacity to regulate serum level of CRP and the inflammatory cytokines will provide an insight to the molecular mechanism behind their anti-inflammatory activities.

For centuries, Curcuma longa L. (Turmeric) rhizomes, a member of the Zingiberaceae family, has been broadly employed as the indigenous medicinal plant especially for the management of diseases associated with inflammation (Ammon and Wahl, 1991). Among the active components of Tumeric, curcumin happens to be the most important, and a vast array of biological and medicinal activities such as antioxidative, anticancinogenic, antimicrobial, antifungal and anti-inflammatory activities to mention a few have been attributed to curcumin (Araujo and Leon, 2001; Maheshwari et al., 2006). Many studies have revealed the curative effects of curcumin against hepatotoxicity and oxidative stress induced by cadmium (Mohajeri et al., 2017), dimethylnitrosamine (Kyung et al., 2018), Thioacetamide (Elmansi et al., 2017), propanil (Otuechere et al., 2014) and cadmium - induced renal toxicity (Akinyemi et al., 2017) in experimental models. Part of its mechanism of action has been reported to be either through direct interaction with molecular targets or alteration of gene expression and signaling pathways (Kyung et al., 2018). Reports on the effectiveness of curcumin in the inhibition of liver cirrhosis through the regulation of many pathways for example, NF$\kappa \mathrm{B}$ pathway and inhibition of oxidative stress has been recently established (Cai et al., 2017). Obaidi et al. (2018) reported the ability of curcumin to suppress the carcinogenic potential of $\mathrm{KBrO}_{3}$ by reducing the level of $\mathrm{H}_{2} \mathrm{O}_{2}$ and 8-OHdG DNA adducts (Obaidi et al., 2017). Despite these reports, the molecular mechanisms behind the hepato-protective activities of curcumin are yet to be fully understood. Here, we account that Curcumin alleviates potassium bromate-induced hepatic damage by repressing CRP induction through TNF- $\alpha$ and IL-1 $\beta$ and by suppressing oxidative stress.

\section{Materials and Methods}

\section{Chemicals and reagents}

Rat C-reactive protein (CRP) Catalog Number.CSBE07922r; rat TNF- $\alpha$ Catalog Number. CSB-E11987r and; rat interleukin-1 $\beta$ (IL-1 $\beta$ ) Catalog Number.CSB-E08055r ELIZA kits were supplied by e-Biosceince, Inc. $\mathrm{KBrO}_{3}$ (CAS NO: 7758), (99\% purity) was supplied by Lab-Tech Chemicals, Curcumin, Glutathione (GSH), 5',5'-dithiobis2-nitrobenzene (DTNB), 2-thiobarbituric acid (TBA), Biuret and 1 chloro-2, 4-dinitrobenzene (CDNB) and hydrogen peroxide $\left(\mathrm{H}_{2} \mathrm{O}_{2}\right)$ were manufactured by SigmaAldrich, St Louis, MO, USA. All other reagents and chemicals used in this study were of analytical grade and water used was glass distilled.

\section{Experimental animals}

The animals used for this study were thirty (30) male rats of Wistar strain, weighing about 160-210 $\mathrm{g}$ and they were obtained from the Central Animal House, College of Health Sciences, Osun State University, Osogbo. These were acclimatized for 7 days in plastic cages in the animal house at an ambient temperature of $25^{\circ} \mathrm{C}$ and a relative humidity of $45-55 \%$, with 12 hours each of dark and light cycles. Animals were sustained on normal laboratory chow and fresh water ad libitum. The handling and use of the animals were in accordance with NIH Guide for the care and use of laboratory animals.

\section{Treatment groups/study design}

Animals were distributed into 5 experimental groups $(n$ $=6$. Saline/vehicle, which is negative control group received oral administration of $0.8 \%$ saline daily, olive oil/vehicle control group received oral administration of olive oil daily. Olive oil/curcumin group received daily oral administration of olive oil containing 20 $\mathrm{mg} / \mathrm{kg} /$ bodyweight of curcumin, $\mathrm{KBrO}_{3} /$ vehicle, which is positive control group received oral administration of $0.8 \%$ saline containing $20 \mathrm{mg} / \mathrm{kg} /$ bodyweight $\mathrm{KBrO}_{3}$ twice a week, $\mathrm{KBrO}_{3} /$ curcumin combination group received daily dose of curcumin and dose of $\mathrm{KBrO}_{3}$ twice a week. In the present study, potassium bromate was orally administered to rats as described by (Khan et al., 2012) and the dosage of $\mathrm{KBrO}_{3}$ was chosen according to previous report (Bayomy et al., 2016) where it induced hepatic functional alterations, while the choice of the curcumin dosage was made based on the acceptable range reported for daily intake (NCI, 1996). $\mathrm{KBrO}_{3}$ was diluted in saline and the curcumin in olive oil; 
both solutions were prepared freshly and administered (1 $\mathrm{mL} / \mathrm{kg}$ ). Curcumin was administered daily while $\mathrm{KBrO}_{3}$ was administered twice weekly and two hours after curcumin. The experiment lasted for a period of 28 days, after which animals were fasted overnight and sacrificed 24 hours after the last dose under light ether anesthesia. Blood samples were obtained by heart puncture and centrifuged at $3000 \mathrm{~g}$ for 10 minutes. The clear non-hemolyzed sera were stored at $-20^{\circ} \mathrm{C}$ till subsequent measurements.

Tissue collection and preparation

The livers were quickly expunged and rinsed in cold $1.15 \% \mathrm{KCl}$ solution, blotted on filter papers to remove adhering blood, and homogenized in $100 \mathrm{mM}$ potassium phosphate buffer, $\mathrm{pH}$ 7.5. The homogenates were centrifuged at $10,000 \mathrm{~g}$ for 20 minutes at $4{ }^{\circ} \mathrm{C}$, and the supernatant was used for subsequent biochemical assays. A fraction was fixed in $10 \%$ neutral buffered formalin solution for histological examination.

Determination of serum hepatic function biomarkers

The hepatic function biomarkers Alanine amino transferases (ALT) and Aspartate amino transferases (AST) activities were determined following the principle reported (Reitman and Frankel, 1957) Alkaline phosphatases (ALP) activity was determined following the method described by Englehardt (1970). Total protein concentrations of the serum were determined according to Biuret method as described by Gornall et al. (1949). Albumin concentration was determined following the principle reported by Grant (1987).

\section{Estimation of antioxidant status}

Catalase (CAT) activity was measured using hydrogen peroxide as the substrate according to the method previously described (Manubolu et al., 2014). Superoxide dismutase (SOD) activity was determined by measuring the inhibition of autoxidation of epinephrine at $\mathrm{pH} 10.2$ and $30{ }^{\circ} \mathrm{C}$ according to Misra and Fridovich (1972). Reduced glutathione (GSH) was determined according to the method of Jollow et al. (1974). Activity of Glutathione peroxidase (GPx) was estimated following the method reported by Rotruck et al. (1973) while Total thiol (TSH) content in the liver homogenate was determined as described by Ellman (1959).

\section{Lipidperoxidation}

Lipid peroxidation was determined as the formation of thiobarbituric acid reactive substances during an acidheating reaction, according to Ohkawa et al. (1979) Briefly, the reaction mixture consisting of $200 \mu \mathrm{L}$ of kidney homogenates or standard $[0.03 \mathrm{mM}$ malondialdehyde (MDA)], $200 \mu \mathrm{L}$ of $8.1 \%$ sodium dodecyl sulfate, $500 \mu \mathrm{L}$ of $0.8 \%$ thiobarbituric acid, and $500 \mu \mathrm{L}$ of acetic acid solution (2.5 M HCl, pH 3.4) was heated at $95^{\circ} \mathrm{C}$ for 1 hour. The absorbance was measured at $532 \mathrm{~nm}$. Tissue levels of thiobarbituric acid reactive substances were expressed as $\mathrm{mmol} \mathrm{MDA} / \mathrm{mg}$ of protein.

Assay of serum $C$-reactive protein, $I L-1 \beta$ and $T N F-\alpha$

Enzyme-linked immunosorbent assay: rat $\mathrm{C}$-reactive protein (CRP); rat TNF- $\alpha$ and rat interleukin-1 $\beta$ (IL-1 $\beta$ ) ELISA Kits were used to measure the concentrations of high sensitive $\mathrm{C}$-reactive protein (CRP), interleukin-1 $\beta$ (IL$1 \beta$ ) and tumor necrosis factor-alpha (TNF- $\alpha$ ) by following the instructional manual.

\section{Histopathological analysis}

The liver tissues were excised from the animals after sacrifice and stored in $10 \%$ formalin solution, for tissue sections and subsequent histopathological examination. The tissues were then embedded in paraffin. A rotary microtome was used to collect five micrometre-thick paraffin sections, and tissues were thereafter stained by hematoxylin and eosin $(\mathrm{H} \& \mathrm{E})$. The specimens were examined and photographed under a light microscope.

\section{Statistical analysis}

The data were expressed as mean \pm standard deviation (SD) after analysis by one-way analysis of variance (ANOVA) with the aid of Graph Pad Prism version 5. for windows (GraphPad software, San Diego, CA), followed by Post hoc Bonferroni comparative test Differences between mean values of different groups were considered statistically significant at $\mathrm{P}<0.05$.

\section{Results}

Effect of curcumin on the some serum hepatic biomarkers in rats exposed to $\mathrm{KBrO}_{3}$

The ability of curcumin to alleviate $\mathrm{KBrO}_{3}$-induced hepatic damage was estimated by determining the activities of AST, ALT and ALP. As shown in Table 1, pre-treatment with curcumin at a dose of $20 \mathrm{mg} / \mathrm{kg}$ significantly reduced the activities of AST, ALT and ALP that were secreted into serum as a result of $\mathrm{KBrO}_{3}$-induced hepatic damage.

Effect of curcumin on serum levels of CRP and inflammatory cytokines in rats exposed to $\mathrm{KBrO}_{3}$

The results that revealed serum levels of CRP and inflammatory cytokines: IL-1 $\beta$ and TNF- $\alpha$ evaluated by ELISA techniques are presented in Table 2 . As shown, in the table, the three proteins were significantly induced subsequent to $\mathrm{KBrO}_{3}$ administration. However, upon oral co-administration with curcumin for 28 days, the serum levels of these proteins were significantly regulated.

Effect of curcumin on markers affected during oxidative stress in rats exposed to $\mathrm{KBrO}_{3}$

Induction of oxidative stress has been reported to be associated with $\mathrm{KBrO}_{3}$-induced hepatic damage in experimental models (Chipman et al., 1998; Umemura et al., 1998; Murata et al., 2001). To corroborate this view, $\mathrm{KBrO}_{3}$ caused a significant reduction in GSH and TSH levels (Figs. 1 and 2), and activities of catalase, SOD and GPx, in the liver homogenate (Figs. 3, 4 and 5) with simultaneous increase in MDA formation (Fig. 6). The effects of $\mathrm{KBrO}_{3}$ on these parameters were adjusted by curcumin. 
Table 1. Effects of curcumin on some serum hepatic biomarkers in rats exposed to $\mathrm{KBrO}_{3}$

\begin{tabular}{cccccc}
\hline & Control & Olive-oil & Curcumin & $\mathrm{KBrO}_{3}$ & $\mathrm{Curcumin}^{2}+\mathrm{KBrO}_{3}$ \\
\hline AST $(\mathrm{u} / \mathrm{l})$ & $88.33 \pm 7.64$ & $85.00 \pm 2.00$ & $86.00 \pm 4.58$ & $189.00 \pm 5.57^{\mathrm{abc}}$ & $112.67 \pm 11.15^{\mathrm{ac}}$ \\
$\operatorname{ALT}(\mathrm{u} / \mathrm{l})$ & $82.33 \pm 2.08$ & $80.00 \pm 1.00$ & $81.00 \pm 7.00$ & $124.33 \pm 4.04^{\mathrm{abc}}$ & $96.33 \pm 5.51^{\mathrm{ac}}$ \\
$\operatorname{ALP}(\mathrm{u} / \mathrm{l})$ & $26.67 \pm 2.08$ & $23.33 \pm 3.51$ & $23.67 \pm 3.21$ & $69.00 \pm 6.55^{\mathrm{abc}}$ & $33.00 \pm 2.65^{\mathrm{ac}}$ \\
\hline
\end{tabular}

Control = group treated with saline; oliveoil = group treated with oliveoil; curcumin = group treated with oliveoil $+20 \mathrm{mg} / \mathrm{kg}$ curcumin only; $\mathrm{KBrO} 3=$ group treated with saline $+20 \mathrm{mg} / \mathrm{kg} \mathrm{KBrO} 3$ only; curcumin $+\mathrm{KBRO}_{3}=$ group treated with $20 \mathrm{mg} / \mathrm{kg}$ curcumin $+20 \mathrm{mg} / \mathrm{kg} \mathrm{KBrO}$; AST = Aspartate transaminase; ALT= Alanine transaminase; ALP = Alkaline phosphatase; $\mathrm{SD}=$ standard deviation. ${ }^{a}$ values are significantly $(\mathrm{p}<0.05)$ different from control, ${ }^{\mathrm{b}}$ values are significantly $(\mathrm{p}<0.05)$ different from curcumin $+\mathrm{KBrO}_{3}$, ${ }^{\mathrm{c}}$ values are significantly $(\mathrm{p}<0.05)$ different from curcumin

Table 2. Effects of curcumin on serum levels of CRP, and IL-1 $\beta$ and TNF- $\alpha$ in rats exposed to KBrO3

\begin{tabular}{cccccc}
\hline & Control & Olive-oil & Curcumin & $\mathrm{KBrO}_{3}$ & $\mathrm{Curcumin}^{2}+\mathrm{KBrO}_{3}$ \\
\hline $\mathrm{CRP}(\mathrm{ng} / \mathrm{mL})$ & $7.46 \pm 0.54$ & $7.10 \pm 0.22$ & $6.32 \pm 0.97$ & $17.35 \pm 1.05^{\text {abc }}$ & $11.08 \pm 0.98^{\mathrm{ac}}$ \\
$\mathrm{IL}-1 \beta(\mathrm{ng} / \mathrm{mL})$ & $76.20 \pm 599$ & $77.12 \pm 5.55$ & $75.72 \pm 5.49$ & $170.17 \pm 5.44^{\mathrm{abc}}$ & $122.25 \pm 12.17^{\mathrm{ac}}$ \\
$\mathrm{TNF}-\alpha(\mathrm{ng} / \mathrm{mL})$ & $20.14 \pm 1.05$ & $22.31 \pm 2.00$ & $20.77 \pm 0.63$ & $80.89 \pm 2.41^{\mathrm{abc}}$ & $44.53 \pm 2.35^{\mathrm{ac}}$ \\
\hline
\end{tabular}

\section{GSH}

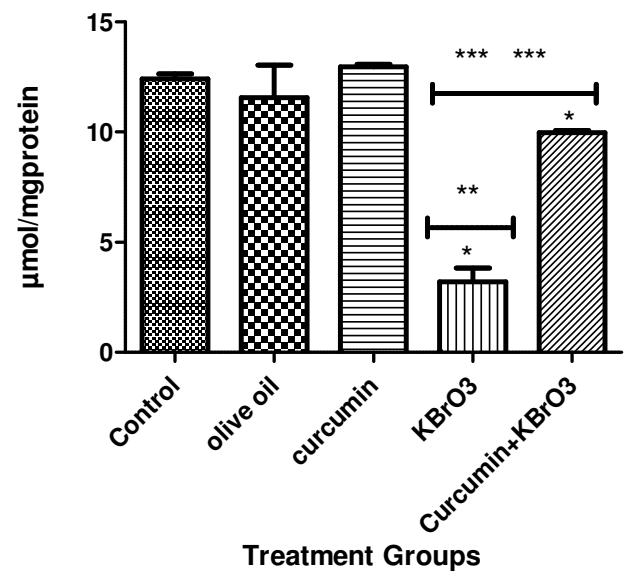

Fig. 1. Effect of curcumin on reduced glutathione (GSH) levels in $\mathrm{KBrO} 3$-induced liver oxidative damage. Data are presented as the mean $\pm S D(n=6) .{ }^{*}$ values are significantly $(p<0.05)$ different from control, ${ }^{* *}$ values are significantly $(\mathrm{p}<0.05)$ different from curcumin $+\mathrm{KBrO}_{3}$, ${ }^{* * *}$ values are significantly $(\mathrm{p}<0.05)$ different from curcumin. For details, see legend in Table 1

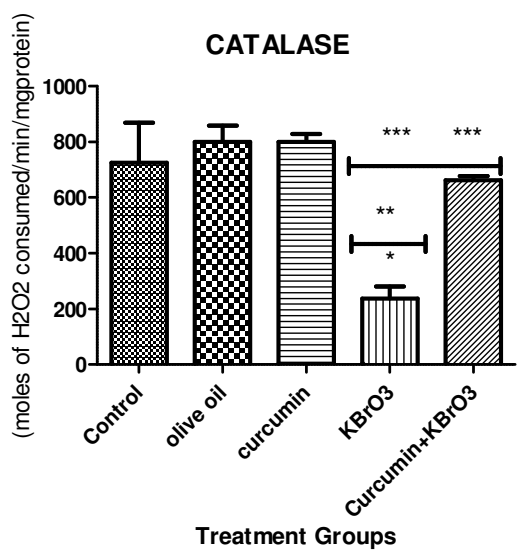

Fig. 3. Effect of curcumin on the activities of catalase in $\mathrm{KBrO} 3$-induced liver oxidative damage. Data are presented as the mean $\pm S D(n=6) .{ }^{*}$ values are significantly $(\mathrm{p}<0.05)$ different from control, ${ }^{* *}$ values are significantly $(\mathrm{p}<0.05)$ different from curcumin $+\mathrm{KBrO} 3,{ }^{* * *}$ values are significantly $(\mathrm{p}<0.05)$ different from curcumin. For details, see legend in Table 1
TSH

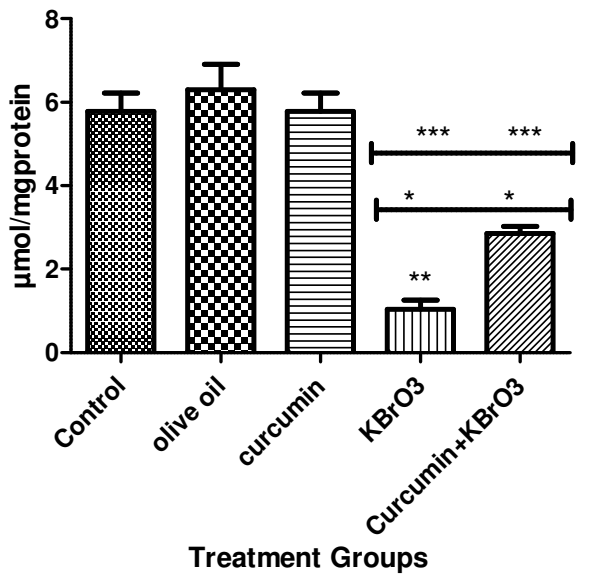

Effect of curcumin on total thiol (TSH) levels in $\mathrm{KBrO} 3$ induced liver oxidative damage. Data are presented as the mean $\pm \mathrm{SD}(\mathrm{n}=6) .{ }^{*}$ values are significantly $(\mathrm{p}<0.05)$ different from control, ${ }^{* *}$ values are significantly $(\mathrm{p}<0.05)$ different from curcumin $+\mathrm{KBrO} 3,{ }^{* * *}$ values are significantly $(\mathrm{p}<0.05)$ different from curcumin. For details, see legend in Table 1

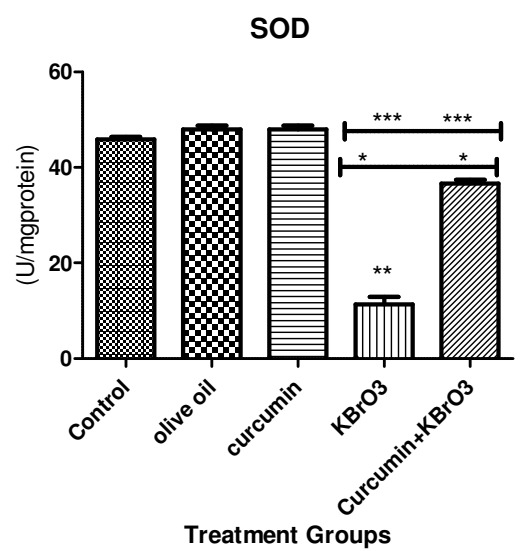

Fig. 4. Effect of curcumin on the activities of superoxide dismutase (SOD) in $\mathrm{KBrO} 3$-induced liver oxidative damage. Data are presented as the mean $\pm S D(n=6) .{ }^{*}$ values are significantly $(p<0.05)$ different from control, ${ }^{* *}$ values are significantly $(p<0.05)$ different from curcumin $+\mathrm{KBrO}$, ${ }^{* * *}$ values are significantly $(\mathrm{p}<0.05)$ different from curcumin. For details, see legend in Table 1 


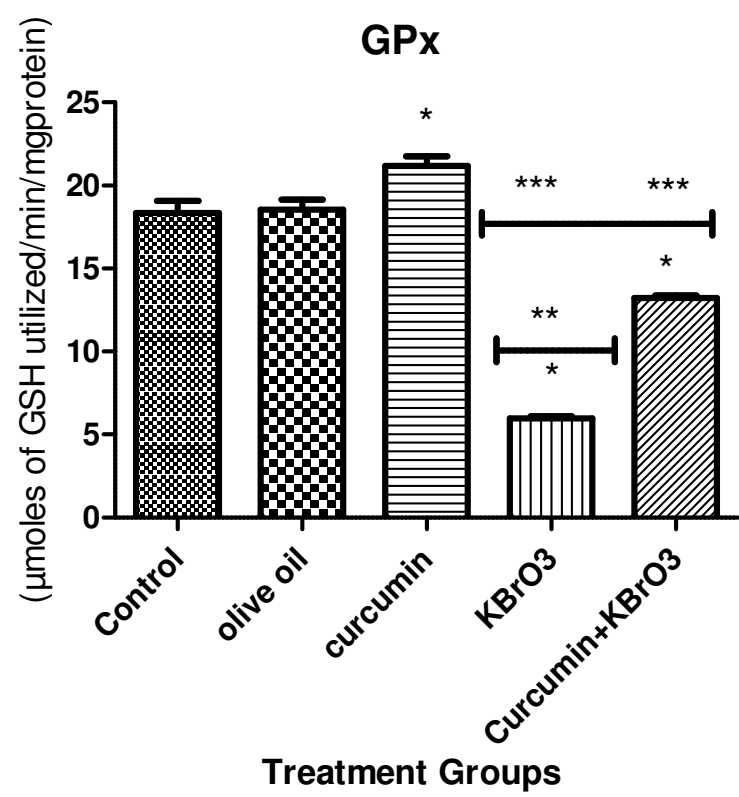

Fig. 5. Effect of curcumin on the activities of glutathione peroxidase (GPx) in $\mathrm{KBrO} 3$-induced liver oxidative damage. Data are presented as the mean \pm SD $(n=6) .{ }^{*}$ values are significantly $(p<0.05)$ different from control, ${ }^{* *}$ values are significantly $(\mathrm{p}<0.05)$ different from curcumin $+\mathrm{KBrO}_{3}$, ${ }^{* * *}$ values are significantly $(\mathrm{p}<0.05)$ different from curcumin. For details, see legend in Table 1

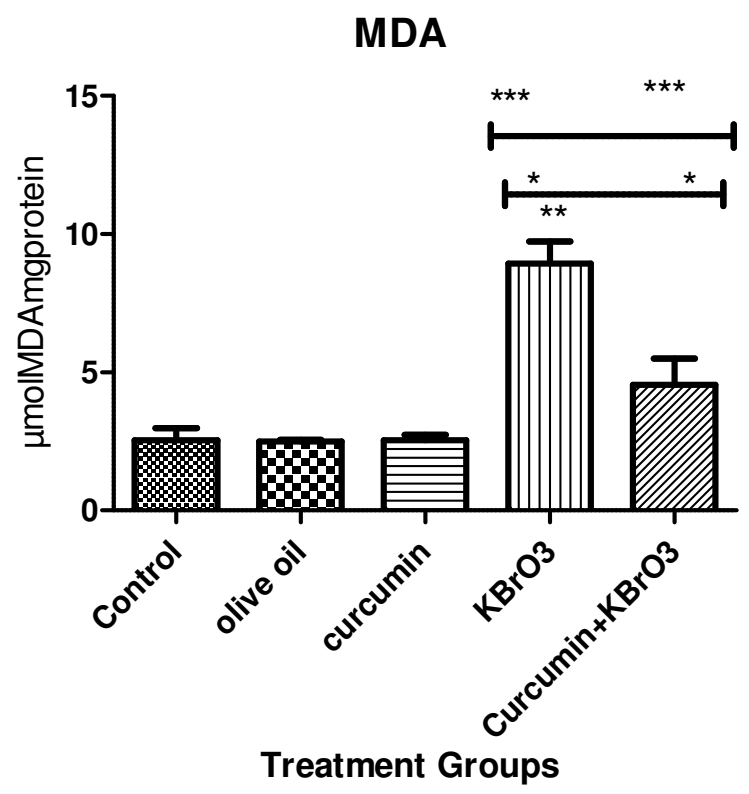

Fig. 6. Effect of curcumin on malondialdehyde (MDA) level in $\mathrm{KBrO} 3$-induced liver oxidative damage. Data are presented as the mean $\pm \operatorname{SD}(n=6) .{ }^{*}$ values are significantly $(\mathrm{p}<0.05)$ different from control, ${ }^{* *}$ values are significantly $(\mathrm{p}<0.05)$ different from curcumin $+\mathrm{KBrO} 3,{ }^{* * *}$ values are significantly $(\mathrm{p}<0.05)$ different from curcumin. For details, see legend in Table 1

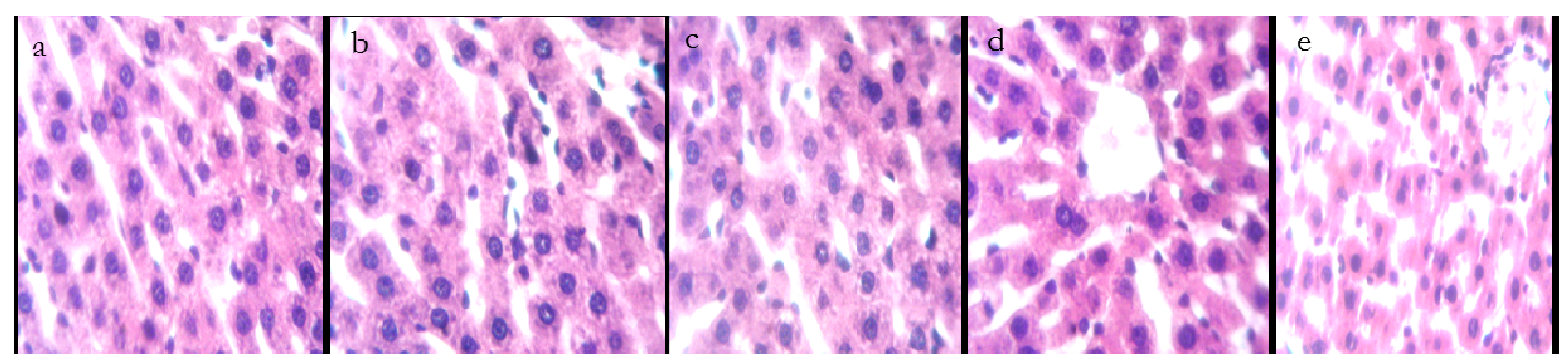

Fig. 7. Representative photomicrographs of liver section viewed under light microscope at magnification 400x; (a) control: showing no visible pathological alteration; (b) oliveoil: showing no visible pathological alteration; (c) curcumin: showing no visible lesion with normal histomorphology of the liver cells; (d) KBrO3: showing severe choleostatsis, the general histomorphology is perturbed (e) $\mathrm{KBrO} 3+$ curcumin: showing typical presentation of liver histomorphology with no pathological alteration. Density and staining intensity appear normal with halo spaced central vein

\section{Effects of curcumin on the liver histology of rats exposed to $\mathrm{KBrO}_{3}$}

Histological examination of liver tissues also supported these results because the liver samples from group treated with $\mathrm{KBrO}_{3}$ showed severe choleostatsis with generally perturbed histomorphology (Fig. 7D) compared with the control and olive-oil liver sections (Fig. 7A and B). In groups treated with curcumin alone and group pre-treated with curcumin before exposure to $\mathrm{KBrO}_{3}$, the hepatocytes have histomorphology with no pathological alteration (Fig. 7C and E).

\section{Discussion}

While anticarcinogenic effects of bioactive components from medicinal plants have been accounted for via various mechanisms (Surh, 2003; Lee et al., 2007; Farombi et al., 2009), research interest is now being drawn on the involvement of signaling molecules mediating the pathways which link inflammation and cancer (Clevers, 2004). As a result, deliberate obstruction of intracellular signaling pathways which mediate inflammatory reaction becomes a critical consideration to successfully build up chemo- 
342

preventive agents which are molecular target-based (Surh $e t$ al., 2005; Farombi et al., 2009). CRP, one of the acute phase proteins (APPs) secreted from the hepatocytes is generally up-regulated in many malignancies including those related to the hepatic cells (De Mello et al., 1983; Falconer et al., 1995; Gockel et al., 2006; Crumley et al., 2006), hence, the deliberate inhibition of signaling network (including e.g. IL$1 \beta$, and TNF- $\alpha$ ) concerned with upregulation of serum CRP level is considered to be effective in the prevention of malignant diseases. To this end, agents with CRP-lowering capacity are being considered to be potentially effective in cancer prevention and therapy (Wang and Sun, 2009) while other attempts have targeted the inducers of CRP i.e. the cytokines (e.g. IL-1 $\beta$, and TNF $\alpha$ ) to indirectly suppress CRP in cancers and diseases associated with Inflammation (Wang and Sun, 2009). Therefore, evaluation of CRP and inflammatory cytokines (e.g. IL-1 $\beta$, and TNF $\alpha$ ) remains relevant in monitoring hepatic toxicity and malignancies.

Reports on the antioxidative, antihepatotoxic and anticarcinogenic properties of curcumin in various experimental models abound (Farombi et al., 2009; Otuechere et al., 2014; Mohajeri et al., 2017; Elmansi et al., 2017; Kyung et al., 2018), but reports on the protective effect of curcumin in $\mathrm{KBrO}_{3}$-induced hepatotoxity is scarce in literature. Obaidi et al. (2018) reported that curcumin was able to abrogate the carcinogenic potential of $\mathrm{KBrO}_{3}$ by reducing the level of $\mathrm{H}_{2} \mathrm{O}_{2}$ and 8-OHdG DNA adduct (Obaidi et al., 2017), however, the molecular mechanisms behind curcumin induced anti hepatotoxicity especially against $\mathrm{KBrO}_{3}$ is yet to be fully deciphered. Here, we account that Curcumin alleviates potassium bromateinduced hepatic damage by repressing CRP induction through TNF- $\alpha$ and IL- $1 \beta$ and by suppressing oxidative stress. The evident reduction in $\mathrm{KBrO}_{3}$-induced increase in the activities of serum enzymes and lipid peroxidation by curcumin in this study corroborates with prior findings on the hepato-protective ability of this natural compound on several hepatotoxicants (Otuechere et al., 2014; Elmansi et al., 2017). The oxidative capacity of $\mathrm{KBrO}_{3}$ has been demonstrated in many organs (Ahmad et al., 2015), $\mathrm{KBrO}_{3}$ is generally known to be an oxidant inducing oxidative damage in several experimental models. Antioxidants which are capable of suppressing the damaging effects of these oxidants get completely overwhelmed and therefore become drastically reduced leading to a condition regarded as oxidative stress (Uchida et al., 2018) It is not surprising that administration of $\mathrm{KBrO}_{3}$ caused significant reduction in both enzymatic and non-enzymatic antioxidant molecules viz: TSH, GSH, GPx, catalase and SOD. This reduction may not be unrelated to the ability of $\mathrm{KBrO}_{3}$ as an oxidant. Antioxidative potential of curcumin is well established (Elmansi et al., 2017; Mohajeri et al., 2017; Kyung et al., 2018). In this study, the combination group that was fortified with curcumin prior to $\mathrm{KBrO}_{3}$ exposure experienced a significant rise all the antioxidant molecules. The fortification of the animals with curcumin may have led to the boosting of the antioxidant status which in turn becomes capable of combating the oxidative ability of $\mathrm{KBrO}_{3}$ in the hepatocytes. The significant increase in lipid peroxidation as evident by high concentration of malonaldehyde (MDA) may be the explanation at least in part for the liver damage observed in this study. The involvement of lipid peroxidation in the damage of cell membrane due to chain reaction is well established (Ayala et al., 2014). The damage caused by increased lipid peroxidation in the liver of the rats treated with $\mathrm{KBrO}_{3}$ may be the cause of the evident hitopathological alterations observed in this group, whereas, the antioxidative capacity of curcumin which prevents lipid peroxidation in the combination group cause a significant prevention of liver damage as shown in the histology of the liver in the combination group.

A link between inflammation and cancer has been established since 1863 when the sites of chronic inflammation were suggested to be the origin of cancer (Balkwill and Mantovani, 2001). A significant association with chronic inflammation (whether infectious or noninfectious causes) has been reported in about $25 \%$ of all cancer cases (Perwez and Harris, 2007), in which there is significant elevation of inflammatory markers. Serum Creactive protein (CRP) has been established as a susceptible indicator for inflammatory activities (Wang and Sun, 2009) and it is reported to be generally up-regulated in several malignancies including those associated with hepatic cells (Crumley et al., 2006; Gockel et al., 2006). Similarly, high level of IL-1 $\beta$ and TNF- $\alpha$ (inducers of CRP) have also been reported to be capable of inducing hepatic damage (DeCicco et al., 1998). As a result of this, agents that lower CRP and its inducers are beneficial in cancer therapy. In this study, administration of $\mathrm{KBrO}_{3}$ caused a significant increase in serum CRP and the inflammatory cytokines IL- $1 \beta$ and TNF- $\alpha$ compared with the control. The ability of $\mathrm{KBrO}_{3}$ to dysregulate markers involved in inflammation has earlier been reported (Obaidi et al., 2017), since $\mathrm{KBrO}_{3}$ has been implicated in different neoplastic transformation, and tumor generation (Nakae et al., 1997; Wills et al., 2006; Pradeep et al., 2007; Uchida et al., 2018) and neoplasm is linked with inflammation (Balkwill and Mantovani, 2001), it may be suggested that inflammation is involved in the mechanisms of $\mathrm{KBrO}_{3}$ - induced carcinogenicity at least in part. Prior administration of curcumin before $\mathrm{KBrO}_{3}$ administration resulted in the modulation of the increase in these markers. This suggests that curcumin may be a good candidate for lowering CRP, hence, suitable for chemoprevention. Also, taking into account the role of CRP and inflammatory cytokines in toxicity and tumor transformation, the suppression of these markers by curcumin in the $\mathrm{KBrO}_{3}$ group somewhat clarifies the molecular mechanism by which curcumin exhibits it hepato-protective effect in $\mathrm{KBrO}_{3}$ - induced hepatic damage and probably hepatic- neoplasm.

\section{Conclusions}

The present study revealed that curcumin regulates the activities and levels of some antioxidant molecules and some enzymes involved in hepatic function in rats exposed to $\mathrm{KBrO}_{3}$. The ability of curcumin to inhibit CRP elevation via suppression of the inflammatory cytokines IL-1 $\beta$ and TNF- $\alpha$ was also shown. Therefore, it can be assumed that the mechanism of the hepatoprotective effect of curcumin in $\mathrm{KBrO} 3$ - induced hepatic damage involves suppression of 
CRP induction through TNF- $\alpha$ and IL-1 $\beta$ and inhibition of oxidative stress. The turmeric plant from which curcumin is isolated is generally known for its medicinal values. In view of this study, addition of curcumin to food may be encouraged to prevent food additive related liver injury.

\section{Acknowledgements}

The authors wish to thank Akanmuli Health Foundation for partial funding of this project.

\section{Conflict of Interest}

The authors declare that there are no conflicts of interest related to this article.

\section{References}

Ahmad MK, Khan AA, Ali SN, Mahmood R (2015). Chemoprotective effect of taurine on potassium bromate-induced DNA damage, DNAprotein cross-linking and oxidative stress in rat intestine.PloS One 10(3):e0119137.

Akinyemi AJ, Onyebueke N, Faboya OA, OnikanniSA, Fadaka A, Olayide I (2017). Curcumin inhibits adenosine deaminase and arginase activities in cadmium-induced renal toxicity in rat kidney. Journal of Food and Drug Analysis 25(2):438-446.

Ammon HP, Wahl MA (1991). Pharmacology of Curcuma longa. Planta Medica 57(1):1-7.

Araujo CAC, Leon LL (2001). Biological activities of Curcuma longa L. Memorias do Instituto Oswaldo Cruz 96(5):723-728.

Ayala A, Muñoz MF, Argüelles S (2014). Lipid peroxidation: production, metabolism, and signaling mechanisms of malondialdehyde and 4 hydroxy-2-nonenal.Oxidative Medicine and Cellular Longevity 2014:1-31.

Balkwill F, Mantovani A (2001). Inflammation and cancer: back to Virchow? Lancet 357:53945.

Bayomy NA, Soliman GM, Abdelaziz EZ (2016). Effect of potassium bromate on the liver of adult male albino rat and a possible protective role of vitamin C: histological, immunohistochemical, and biochemical study. The Anatomical Record 299(9):1256-1269.

Cai Y, Lu D, Zou Y, Zhou C, Liu H, Tu C, ... Zhang S (2017). Curcumin protects against intestinal origin endotoxemia in rat liver cirrhosis by targeting PCSK9. Journal of Food Science 82(3):772-780.

Castell JV, Gomez-Lechon MJ, David M, Fabra R, Trullenque R, Heinrich PC (1990). Acute-phase response of human hepatocytes; regulation of acute-phase protein synthesis by interleukin-6. Hepatology 12:1179 1186.

Chipman J, Davies J, Parsons J, Nair G, O’Neill J, Fawell J (1998). DNA oxidation by potassium bromate; a direct mechanism or linked to lipid peroxidation? Toxicology 126:93-102.

Clevers H (2004). At the crossroads of inflammation and cancer. Cell 118:671-674.

Crumley ABC, McMillan DC, McKernan M, GoingJJ, Shearer CJ, Stuart RC (2006). An elevated C-reactive protein concentration, prior to surgery, predicts poor cancer-specific survival in patients undergoing resection for gastrooesophageal cancer. British Journal of Cancer 94:1568-71

De Mello J, Struthers L, Turner R, Cooper EH, Giles GR (1983). Multivariate analyses as aids to diagnosis and assessment of prognosis in gastrointestinal cancer. British Journal ofCancer 48:341-348.

DeAngelo AB, George MH, Kilburn SR, Moore TM, Wolf DC (1998). Carcinogenicity of potassium bromate administered in the drinking water to male $\mathrm{B} 6 \mathrm{C} 3 \mathrm{~F} 1$ mice and $\mathrm{F} 344 / \mathrm{N}$ rats. Toxicologic Pathology 26(5):587-594.

DeCicco LA, Rikans LE, Tutor CG, Hornbrook KR (1998). Serum and liver concentrations of tumor necrosis factor $\alpha$ and interleukin- $1 \beta$ following administration of carbon tetrachloride to male rats. Toxicology Letters 98(1-2):115-121.

Elmansi AM, El-Karef AA, El-Shishtawy MM, Eissa LA (2017). Hepatoprotective effect of curcumin on hepatocellular carcinoma through autophagic and apoptic pathways. Annals of Hepatology 16(4):607-618.

Englehardt A (1970). Measurement of alkaline phosphatase. Aerztl Labor 16(42):1.

Falconer JS, Fearson KC, Ross JA, Elton R, Wigmore SJ, Garden OJ, Carter DC (1995). Acute-phase protein response and survival duration of patients with pancreatic cancer. Cancer 75:2077-82.

Farombi EO, Shrotriya S, Surh YJ (2009). Kolaviron inhibits dimethyl nitrosamine-induced liver injury by suppressing COX-2 and iNOS expression via NF- $k$ B and AP-1.Life Sciences 84(5-6):149-155.

Fürst R, Zündorf I (2014). Plant-derived anti-inflammatory compounds: hopes and disappointments regarding the translation of preclinical knowledge into clinical progress. Mediators of Inflammation 2014(1):146832.

Gockel I, Dirksen K, Messow CM, Junginger T (2006). Significance of preoperative C-reactive protein as a parameter of the perioperative course and long-term prognosis in squamous cell carcinoma and adenocarcinoma of the oesophagus. World Journal of Gastroenterology 12:3746-50.

Gornall AG, Bardawill CJ, David MM (1949). Determination of serum proteins by means of the biuret reaction.Journal of Biological Chemistry 177(2):751-766.

Grant GH (1987). Amino acids and protein; fundamentals of clinical chemistry. In: Tietz NW (Ed). WB Saunders Company Philadelphia USA pp 328-329.

Griffiths K, Aggarwal B, Singh R, Buttar H, Wilson D, De Meester F (2016). Food antioxidants and their anti-inflammatory properties: a potential role in cardiovascular diseases and cancer prevention. Diseases 4(3):28.

Jollow DJ, Mitchell JR, Zampagione NA, Gillette JR (1974). Bromobenzene-induced liver necrosis. Protective role of glutathione and evidence for 3, 4 bromobenzene oxide as the hepatotoxic metabolite. Pharmacology 11(3):151-169.

Kennon S, Price CP, Mills PG, Ranjadayalan K, Cooper J, Clarke H, Timmis AD (2001). The effect of aspirin on C-reactive protein as a marker of risk in unstable angina. Journal of the American College of Cardiology 37:1266-1270.

Khan RA, Khan MR, Sahreen S (2012). Protective effects of rutin against potassium bromate induced nephrotoxicity in rats.BMC complementary and alternative Medicine 12(1):204. 
344

Kyung EJ, Kim HB, Hwang, ES, Lee S, Choi BK, Kim JW, ... Woo EJ (2018). Evaluation of hepatoprotective effect of curcumin on liver cirrhosis using a combination of biochemical analysis and magnetic resonance-based electrical conductivity imaging. Mediators of Inflammation 5491797.

Lee JC, Kundu JK, Hwang DM, Na HK, Surh YJ (2007). Humulone inhibits phorbol ester-induced COX-2 expression in mouse skin by blocking activation of NF- $k \mathrm{~B}$ and $\mathrm{AP}-1$ : I $\mathrm{kB}$ kinase and c-Jun-Nterminal kinase as respective potential upstream targets. Carcinogenesis 28(7):1491-1498.

LiS, Tan HY, Wang N, ZhangZJ, Lao L, WongCW, Feng Y (2015). The role of oxidative stress and antioxidants in liver diseases. International Journal of Molecular Sciences 16(11):26087-26124.

Maheshwari RK, Singh AK, Gaddipati J, Srimal RC (2006). Multiple biological activities of curcumin: A short review. Life Sciences 78(18):2081-2087.

Manubolu M, Goodla L, Ravilla S, Thanasekaran J, Dutta P, Malmlöf K, Obulum VR (2014). Protective effect of Actiniopteris radiata (Sw.) Link. against $\mathrm{CCl} 4$ induced oxidative stress in albino rats.Journal of Ethnopharmacology 153(3):744752.

Misra HP, Fridovich I (1972). The role of superoxide anion in the autoxidation of epinephrine and a simple assay for superoxide dismutase. Journal of Biological Chemistry 247(10):3170-3175.

Mohajeri M, Rezaee M, Sahebkar A (2017). Cadmium-induced toxicity is rescued by curcumin: a review. Biofactors 43(5):645-661.

Murata M, Bansho Y, Inoue S, Ito K, Ohnishi S, Midorikawa K, Kawanashi $S$ (2001). Requirement of glutathione and cysteine in guanine-specific oxidation of DNA by carcinogenic potassium bromated. Chemical Research in Toxicology 14:678-685.

Nakae D, Kobayashi Y, Akai H, Andoh N, Satoh H, Ohashi K, ... Konishi $\mathrm{Y}$ (1997). Involvement of 8-hydroxyguanine formation in the initiation of rat liver carcinogenesis by low dose levels of $\mathrm{N}$-nitrosodiethylamine. Cancer Research 57:1281-1287.

NCI D (1996). Clinical development plan: curcumin. Journal of Cellular Biochemistry Supplement 26:72-85.

Nissen SE, Tuzcu EM, Schoenhagen P, Crowe T, Sasiela WJ, Tsai J,... Ganz P (2005). Reversal of atherosclerosis with aggressive lipid lowering (REVERSAL) investigators. statin therapy, LDL cholesterol, C-reactive protein, and coronary artery disease. New England Journal of Medicine 352:29-38.

Obaidi, I, Higgins M, Bahar B, Davis JL, McMorrow T (2018). Identification of the multifaceted chemopreventive activity of curcumin against the carcinogenic potential of the food additive, $\mathrm{KBrO} 3$. Current Pharmaceutical Design 24(5):595-614.

Ohkawa H, Ohishi N, Yagi K (1979). Assay for lipid peroxides in animal tissues by thiobarbituric acid reaction. Analytical Biochemistry 95(2):351-358.

Otuechere CA, Abarikwu SO, Olateju VI, Animashaun AL, Kale OE (2014). Protective effect of curcumin against the liver toxicity caused by propanil in rats. International Scholarly Research Notices 2014:853697.

Paglia DE, Valentine WN (1967). Studies on the quantitative and qualitative characterization of erythrocyte glutathione peroxidase. The Journal ofLaboratory and Clinical Medicine 70(1):158-169.
Perwez Hussain S, Harris CC (2007). Inflammation and cancer: an ancient link with novel potentials. International Journal of Cancer 121(11):2373-2380.

Pradeep K, Mohan CV, Gobianand K, Karthikeyan S (2007). Effect of Cassia fistula Linn. leaf extract on diethylnitrosamine induced hepatic injury in rats. Chemico Biological Interaction 167:12-18.

Prasad K (2006). C-reactive protein (CRP)-lowering agents. Cardiovascular Drug Review 24:33-50.

Reitman S, Frankel S (1957). A colorimetric method for determination of serum glutamic oxaloacetic and glutamic pyruvic transaminases. American Journal of Clinical Pathology 28:56-62.

Sahreen S, Khan MR, Khan RA, Shah NA (2013). Effect of Carissa opaca leaves extract on lipid peroxidation, antioxidant activity and reproductive hormones in male rats. Lipids in Health and Disease 12(1):90.

Starek A, Beata S (2016). Toxicological properties of potassium bromate. Journal of Pharmaceutical Reports 1:1-9.

Surh YJ (2003). Cancer chemoprevention with dietary phytochemicals. Nature Reviews Cancer 3(10):768-780.

Surh YJ, Kundu JK, Na HK, Lee JS (2005). Redox-sensitive transcription factors as prime targets for chemoprevention with anti-inflammatory and antioxidative phytochemicals. Journal of Nutrition 135:2993S$3001 S$.

Tsuchiya T, Kijima A, Ishii Y, Takasu S, Yokoo Y, Nishikawa A, ... Umemura T (2018). Mechanisms of oxidative stress-induced in vivo mutagenicity by potassium bromate and nitrofurantoin.Journal of Toxicologic Ppathology31(3):179-188.

Uchida T, Sakashita Y, Kitahata K, Yamashita Y, Tomida C, Kimori Y, ... Higashitani A (2018). Reactive oxygen species upregulate expression of muscle atrophy-associated ubiquitin ligase $\mathrm{Cbl}-\mathrm{b}$ in rat L6 skeletal muscle cells. American Journal of Physiology-Cell Physiology 314(6):C721731.

Umemura T, Takagi A, Sai K, Hasegawa R, Kurokawa Y (1998). Oxidative DNA damage and cell proliferation in kidneys of male and female rats during 13-weeks exposure to potassium bromate $\left(\mathrm{KBrO}_{3}\right)$. Archives of Toxicology 72:264269.

Wang CS, Sun CF (2009). C-reactive protein and malignancy: clinicopathological association and therapeutic implication. Chang Gung Medical Journal 32(5):471-482.

Wills PJ, Suresh V, Arun M, Asha VV (2006). Antiangiogenic effect of Lygodium flexuosum against N-nitrosodiethylamine-induced hepatotoxicity in rats. Chemico-Biological Interaction 164:25-38.

Zhang X, De Silva D, Sun B, Fisher J, Bull RJ, Cotruvo JA, Cummings BS (2010). Cellular and molecular mechanisms of bromate-induced cytotoxicity in human and rat kidneycells. Toxicology 269(1):13-23.

Zhou Z, Xu MJ, Gao B (2016). Hepatocytes: a key cell type for innate immunity. Cellular and Molecular Immunology 13(3):301-315.

Zimmerman MA, Selzman CH, Cothren C, Sorensen AC, Raeburn CD, Harken AH (2003). Diagnostic implications of C-reactive protein. Archives of Surgery 138:220-224. 